\title{
Contractual relations of participants in the life cycle of a construction project
}

\author{
Elena Gusakova ${ }^{1 *}$ and Aleksandr Pavlov ${ }^{2}$, \\ ${ }^{1}$ Moscow State University of Civil Engineering, Yaroslavskoe shosse, 26, Moscow, 129337, Russia \\ ${ }^{2}$ All-Russian Research Institute for Nuclear Power Plants Operation (VNIIIAES); Moscow, Russia
}

\begin{abstract}
Contracts accompany all stages of the life cycle of a construction object. The contractual relationship should ensure a balance of production and economic interests of numerous participants in the construction project and stakeholders of the project. When a project is being implemented by several dozen contractors, it is difficult to achieve a balance of interests, the content of contracts is often multidirectional or contradicts each other. In order to systematize the relationships of the project participants, contractual relations in the construction industry and the functions of the subjects of contracts are analyzed. The structure of contracts in construction, based on the cash flow of the project, is proposed. Allocated 6 groups of contracts: agreements concluded by the investor; contracts concluded by the developer, employer; contract agreements; contracts for the supply of goods and the provision of services; collective and individual labor contracts. The main features of each group of agreements and the functions of the subjects of agreements in Russia and abroad are considered. It is shown that, as part of the theory of project management, it is relevant and expedient to develop a section on the structure of contracts, planning a contract campaign and support for a complex of project contracts. It is proposed to develop contracts and think through the contractual terms of the project agreed, under the leadership of the project management team.
\end{abstract}

\section{Introduction}

When they talk about contracts in the construction industry, the thought of building contracts immediately comes to mind. Meanwhile, these contracts are only a small part of the variety of relationships that is present in construction projects. The contractual relationship permeates all stages of the life cycle of a construction object. Basically, these are relations of equal partners, so they take the form of contracts.

Contracts in construction are very significant, which is determined not only by the heterogeneity of the subject and functions of contracts or organizational and managerial features of construction [1, 2, 3]. Pandemic stress in the economy of 2020 especially clearly revealed in the construction contracts in the high risks of long-term relationships between participants, high uncertainty in the content and significance of economic, organizational, technological and legislative factors of influence on the project $[4,5,6]$.

\footnotetext{
*Corresponding author: gusakovaea@mgsu.ru
} 
At the same time, in the theory of project management there is no section dedicated to the development and maintenance of contracts $[7,8]$. In the authors' opinion, this is due to the fact that project management is focused mostly on the implementation of internal or local projects, most of the participants in which are concentrated in one construction firm [9]. Therefore, in the project management team, as a rule, there is no person coordinating the development of contract texts. When a construction project is implemented by several contractors, it is much more difficult to find a balance of interests in the system of contracts $[10 \div 12]$. This leads to the fact that the formation of contractual relations takes a lot of precious time, the provisions of the contracts are in different directions or contradict each other, require constant adjustment. As a result, the contracts themselves are treated without due respect $[13 \div 16]$.

\section{Materials}

The options for relationships in the field of construction activities are very diverse $[17,18$, 19]. At the same time, in external (or object) construction projects, which include several organizations as project participants, these are all orders carried out under concluded contracts. Accordingly, there are a large number of types of contracts, which almost always provide for payment for services, works, goods [20].

Analysis of contractual relations in the construction industry in terms of the main functions of the subject of the contract and methods of structuring them into groups make it possible to systematize the various and dynamic relationships of participants in the project life cycle. On the basis of these methods, it will be easier in the future to determine approaches to the typification of contract conditions and the management of contractual relationships between project participants.

\section{Results}

The following main groups of contracts in construction can be distinguished:

- agreements concluded by the investor;

- contracts concluded by the developer,

- employer;

- contract agreements;

- contracts for the supply of goods and the provision of services;

- collective and individual labor contracts.

It is logical to represent the considered groups of contracts graphically as a sequence of concentric circles in which the flow of funds goes from the center to the periphery. Thus, at the center of the project is the source of funding (see Fig. 1). 


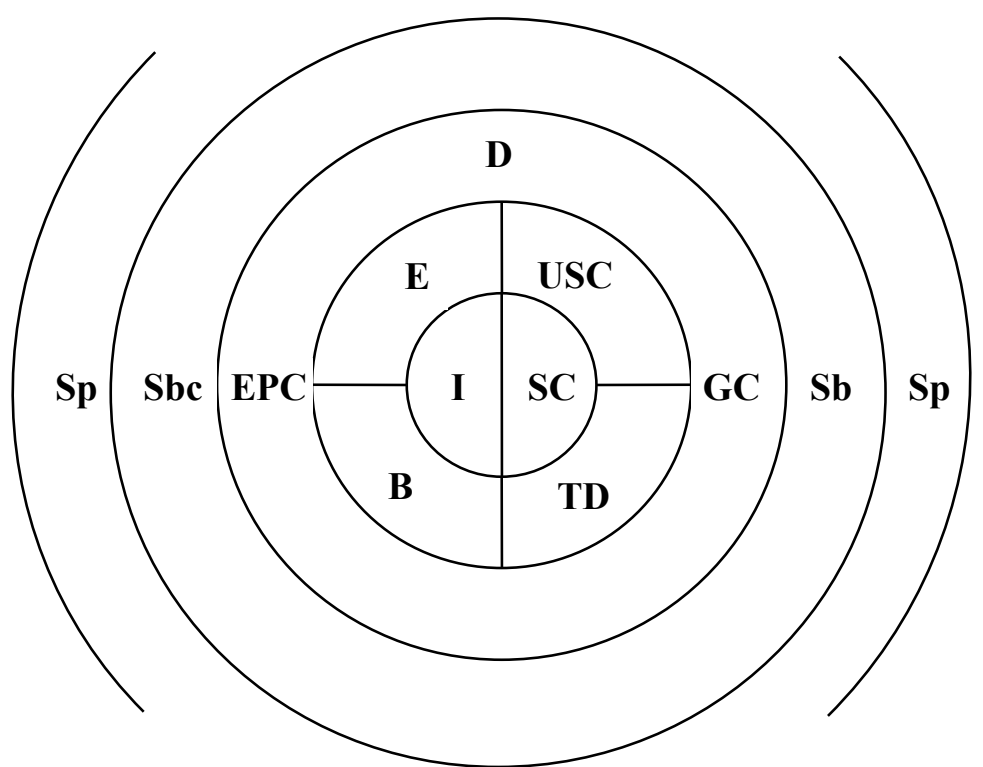

Fig. 1. Subjects of contractual relations in a construction project

I - Investor; SC - State Customer; E - Employer; USC - Unified State Customer; B - Bank; TD Treasury Department; EPC - EPC-contractor; GC - General Contractor; D - designer; Sbs Subcontractors; $\mathrm{Sp}$ - suppliers

\section{Discussion}

Let's consider the main features of these groups. At the same time, not so much real legal entities are considered as subjects of the contract, but rather a certain functionality of the participant. For example, an investor, developer, customer and user of an object may be the same person.

It should also be borne in mind that in many countries there are two sub-sectors of construction: budgetary and corporate, or private. So, in France, public construction objects (travaux publics) are mainly infrastructure facilities, and private construction objects (travaux privés) are civil and industrial buildings. In general, the industry unites construction and public works (bâtiment et travaux publics).

The peculiarity of Russian realities is that the methods of obtaining orders, the level of prices and profitability for contractors in these sub-sectors differ significantly. In the budgetary "half" of construction, the financing party is the state (municipal, hereinafter the state) customer, and in the corporate - the investor. Of course, there can be joint investment.

The contracts concluded by the investor ensure the legal and economic conditions for construction. These may include:

- contracts for the purchase and sale of a land plot or a lease agreement for a plot;

- agreements of joint investment and public-private partnership;

- lending and construction financing agreements;

- contract with an employer;

- contract with an engineer (technical agent, engineering firm);

- agreement on the sale or transfer of the constructed object.

An important area of the investor's activity is to provide reliable financing for construction. For this, contracts are concluded with banks for lending and settlement and cash services. 
A government customer can conclude approximately the same set of contracts, in particular, public-private partnership contracts, contracts for performing the functions of an employer, etc. However, the financing to the state customer is allocated by the manager of budgetary funds on the basis of the decision of the representative body of power - federal, regional or municipal. This financing is made without contractual relations, due to the functions assigned to them by law. To finance the construction projects of the state order, a special type of bank is involved - the treasury. The estimated cost of government orders should not exceed the marginal cost determined by government prices. In particular, an agreement with an engineering firm is not concluded if the budget does not allocate funds for this purpose.

A feature of contracts executed with budgetary funding is the guarantee of payment from the customer, therefore, all over the world, receiving a state order is considered a great success for the contractor. However, in Russia, obtaining such an order is often associated with economic difficulties. This is due, on the one hand, to tight control over the cost, on the other, to the inertia of the bureaucratic system and delays in budget financing, reaching up to several months.

In addition, in the conditions of Russia, the state customer rarely acts as a buyer of land plots, since up to now over $92 \%$ of the land is in state ownership.

Often government customers conclude contracts for design and performance of the functions of an employer at the same time. There is also a construction order with the simultaneous performance of the functions of an employer.

In Russian legislation, there is also a special entity that has the rights to a land plot and conducts construction on it - a developer (zastroyshchik). However, he is not required to be an investor. For example, in case of equity participation in the construction of apartment buildings, future tenants are the investors, and the construction on the acquired plot is carried out by a special developer company. Until the sale of the apartment, funds are accumulated in escrow accounts. In foreign practice, he is most consistent with the concept of "Owner", "Bauherr" (German), but he, as a rule, finances the project.

The main functions of the developer are obtaining a building permit and putting the facility into operation. A design permit is not required under Russian legislation. The rest of the functions can be transferred to the employer.

The employer, in turn, prepares and concludes contracts for design and survey work, for construction work and for the supply of technological equipment, and accepts the results of the work. If you are planning an EPC-contract, you can have a single contract for all types of work and equipment delivery.

Recently, there has been a tendency in Russia to unite the services of an in the person of a single state customer. This method is successfully used in Moscow. However, at the federal level, no structure has yet been created that can unite the gigantic financial flows of budgetary investments in all industries.

The main functions of an employer include:

- development of a general construction management plan;

— interaction with authorities and municipal authorities when obtaining permits and approvals;

- preparation of tasks and the necessary initial data;

- organization of tender procedures for the selection of other performers, suppliers and contractors;

- coordination and control of design and survey, construction and installation, commissioning works;

- acceptance of work results and commissioning of the facility.

The specific scope of the employer's functions significantly depends on the main scheme of construction organization, on the structure of contracting relations and options 
for organizing construction. For example, in new construction, the customer usually begins with the conclusion of contracts for the placement of offices, rental of residential premises, transport passage and parking of vehicles, preparatory work, provision of the construction with electricity, water, etc.

The customer's engineer is involved in the work if the employer cannot fully provide the functionality assigned to him by the investor. In some cases, the investor (bank) recommends that the employer engage an independent firm as an engineer. At the same time, this firm performs functions characteristic of an engineer, but the payment for the services of an engineer is included in the construction estimate. The powers of the engineer to check the state of affairs at the construction site must be specified in the contracts with the employer and the general contractor. The main services of an engineer can be:

- Verification and approval of working documentation;

- Technical control of manufacturing, delivery, storage, conservation, deconservation, revision, installation of technological equipment, including the participation of the engineer's representatives in factory tests;

- Quality control of building materials, products and structures supplied by the contractor, including the analysis of quality control systems and participation in the acceptance and verification of material resources;

- Technical control over the preparatory, construction and installation, commissioning, including participation in the acceptance of the work performed;

- Control over the coordination of work by the general contractor;

- Control over the qualifications of contractors' personnel;

- Control over compliance with the project implementation schedule and fulfillment of mutual obligations of the parties;

- Verification and approval of executive documentation;

- Assistance to the employer in obtaining an opinion on the compliance of the constructed facility with the requirements of technical regulations and design documentation and other documents on the completion of construction.

At industrial construction sites, an employer or an EPC contractor concludes contracts for the supply of technological equipment. These contracts are referred to as sales contracts. The list of supplied equipment indicates the name and purpose of the equipment, main technical characteristics, packaging, labeling and storage features, number of units. In some cases, reference may be made to a published standard that provides information on these characteristics. The delivery schedule contains a list of key dates, such as the date of receipt of advance payment, shipment, acceptance, the estimated date of commencement of operation.

Finally, the employer enters into a contract with the general contractor to carry out construction and installation work. If an EPC contract is being executed, then the EPC contractor is the general contractor. In Russia, a general contractor is, as a rule, a diversified construction organization, which allows him to go through the first difficult stage of construction development. In world practice, there are various options for general contracting. So, in the UK and the countries of the British Commonwealth, the term "main contractor" is used to conclude contracts for construction work. However, in large projects, the main contractor can manage the construction, while the general contractor performs the work independently and hires subcontractors. On government orders, general contractors can also be called "primary contractors".

Large projects in France with dozens of contractors are usually organized by the general contractor (Entreprise générale), although a consortium of contractors can also be created.

On large industrial construction sites in Germany, several general contractors may be present (Generalunternehmer), for example, for construction work, for installation of equipment, for design, each of which can conclude a contract with the customer. If the 
general contractor does not perform at least some of the work on his own, he is called the "general successor" (Generalübernehmer). The work can be coordinated by a common contractor (Totalunternehmer). The term "main contractor" (Hauptunternehmer) is usually applied to the execution and coordination of work on the supporting structures. Such a scheme justifies itself at the final stage of construction, since the general contractor for construction work may experience difficulties in commissioning technological equipment.

The general contractor, in turn, enters into contracts with subcontractors for the performance of certain types of work: construction, installation, repair, commissioning, etc. Thus, the general contractor is in many cases the liaison between the employer and the subcontractors. In relation to the customer, the main duties of the general contractor are:

- Development and application of the necessary technological documentation;

- Erection of a construction object, performance of work in accordance with design and working documentation;

- Implementation of construction control over compliance with the requirements of technical regulations and documentation;

- Maintenance of as-built documentation and its transfer to the customer;

- Ensuring labor safety and environmental safety;

- Ensuring the safety of the object and order at the construction site;

- Compliance with the requirements of the local administration to maintain order in the adjacent territory.

On the other hand, the main responsibilities of the general contractor towards the subcontractors are:

- Provision of production and sanitary facilities for the personnel of the subcontractor;

- Provision of warehouses and sites for storage of materials, structures and equipment of the subcontractor with the summing up of the necessary communications (water supply, electricity, communications, etc.), as well as obtaining technical conditions for temporary connection to engineering networks;

- Transfer of working documentation required for construction;

- Complete transfer of building materials and structures, the delivery of which is entrusted to the general contractor in accordance with the subcontract agreement (dividing list);

- Ensuring the construction readiness of the "work front", that is, the allocation of an area on which all the necessary previous work has been completed;

- Coordination of the activities of subcontractors in the course of work, including commissioning organizations,;

- Timely construction control, acceptance and payment of works.

For his part, the subcontractor is obliged:

- Take all necessary measures to ensure the safety of the property received from the customer;

- Use materials sparingly, give a report on the use of the material of the general contractor or customer;

- Start work on time and get the finished result on time;

- Comply with the agreed requirements for the quality of work;

- Transfer information regarding the maintenance of the subject of the contract;

- Be responsible for the quality of the materials provided to them;

- To suspend the performance of work in case of detection of the unfitness of materials, equipment or documentation.

Finally, the last concentric circle of the construction project is contracts for the supply of building materials and structures, as well as contracts for the lease (purchase) of construction equipment. Typically, each subcontractor supplies the necessary materials for 
their activities. At the same time, the main lifting equipment and vehicles can be provided by the general contractor.

The supply agreement provides for the price and settlement procedure, type of franco. The moment of transfer of ownership of the transferred goods, the return of packaging, warranty obligations of the supplier, mutual sanctions in case of delays in delivery or payment may also be indicated. The required quality of building materials and structures is negotiated, as a rule, by mentioning the standards or technical conditions that the supplied goods must comply with. The requirements for packaging and labeling of goods are also usually mentioned there. Special requirements can be stated in the annex to the contract. Metal, reinforced concrete and wooden structures are usually made according to the drawings of design organizations or according to albums of standard structures.

When ordering materials, it is necessary to calculate the need for them by quarters and months, and sometimes by days of construction, fix this schedule in the annex to the contract. Similarly, the schedule for the delivery of structures is fixed, indicating their brands.

When drafting contracts, model texts are often used, for example, FIDIC model contracts. The main recommended FIDIC contracts are dedicated to complex contracts, construction and installation works, consultant services $<$ https://fidic.org/bookshop $>$. It should be noted that such contracts apply in many, but not all, countries. In Russia, the standard conditions of state contracts for construction work were approved only in 2020 and have a number of disadvantages.

\section{Conclusions}

Thus, the life cycle of a construction project is accompanied and developed with the help of dozens of various contracts that literally permeate the entire system of production and economic relations of participants and stakeholders of the project. Meanwhile, the greatest attention is traditionally paid to building contracts, which constitute only a small part of the total number of contracts.

To understand the general structure of the contractual relationship of project participants, it is necessary to develop a section on the conclusion and maintenance of a set of project contracts as part of the project management theory. The authors propose to develop project contracts in an agreed manner, under the guidance of the project management team.

A special project participant is needed to coordinate the development of the texts of the agreements. It is advisable to include the development of draft contracts, as well as the provisions of project management as a whole, as a separate section in the project documentation. This will allow for the tender stage of the project to prepare lots, texts of contracts, the composition of payment stages, the required volumes of main work and supplies.

\section{References}

1. L. Ma. Y. Le, Q. He, J. Zhang, Research on Organization Integration System towards Large and Complex Building Projects-From Life Cycle Perspective, Procedia - Social and Behavioral Sciences, 74, 31-40, (2013).

2. M. Bahramian, K. Yetilmezsoy, Life cycle assessment of the building industry: an overview of two decades of research (1995-2018), Energy and Buildings, 109917 March (2020). 
3. L.S. Goel Ashish, K. G. Arshinder, Sustainability integration in the management of construction projects: A morphological analysis of over two decades' research literature, Journal of Cleaner Production, 236, 117676, (2019).

4. H. Öncü, U. Gündüz, A classification and review of approaches and methods for modeling uncertainty in projects, International Journal of Production Economics, 107522, (2019).

5. K. Figueiredo, A. W. Hammad, A., Haddad Sustainable Construction Achieved Through Life Cycle Assessment: Methodology, Limitations and the Way Forward, Encyclopedia of Renewable and Sustainable Materials, 4, 576-583, (2020).

6. P. Hopkinson, R. De Angelis, M. Zils, Systemic building blocks for creating and capturing value from circular economy, Resources, Conservation and Recycling. 155, 104672, (2020).

7. O.N. Ilyina, Project management methodology: formation, current status and development (Moscow: Infra-M. 208 p., 2016). (In Russian)

8. G. Pérez, L. Cabeza, Buildings Life Cycle Assessment, Encyclopedia of Sustainable Technologies, Pp. 275-290, (2017).

9. A.S. Pavlov, A.V. Ginzburg, E.A. Gusakova, P.B. Kagan, Management of large-scale projects for the construction of industrial facilities. Monograph. - Ministry of Science and Higher Education of the Russian Federation, National Research Moscow State University of Civil Engineering (Moscow: Publishing house MISI - MGSU, 188 p., 2019). (In Russian)

10. M.K. Mok, G. QipingShen, A network-theory Based Model for Stakeholder Analysis in Major Construction Projects, Procedia Engineering, 164, 292-298 (2016).

11. N.P. Srinivasan, S. Dhivya, An empirical study on stakeholder management in construction projects, Materialstoday PROCEEDINGS, 21, Part 1, 60-62, (2020).

12. M. Birasnav, J. Bienstock, Supply chain integration, advanced manufacturing technology, and strategic leadership: An empirical study. Computers \& Industrial Engineering, 130, 142-157 (2019).

13. G. Ashish, L.S. Ganesh, K. Arshinder, Sustainability integration in the management of construction projects: A morphological analysis of over two decades' research literature, Journal of Cleaner Production, 236, 117676 (2019).

14. G. Eken, G. BilginIrem, M. Dikmen, T. Birgonul, A lessons-learned tool for organizational learning in construction, Automation in Construction, 110, February, 102977 (2020).

15. S. Malik, F. Fareena, I. Asma, F. Lai, Improved project control for sustainable development of construction sector to reduce environment risks, Journal of Cleaner Production, 240, 118214 (2019).

16. R. Picciotto, Towards a 'New Project Management' movement? An international development perspective, International Journal of Project Management, August (2019).

17. A. M. Guido Araújo, R. P. Palha, Sustainable construction management: A systematic review of the literature with meta-analysis // Journal of Cleaner Production, 256, 120350 (2020).

18. K. Antonopoulou, C. Begkos, Strategizing for digital innovations: Value propositions for transcending market boundaries, Technological Forecasting and Social Change. 156, $120042(2020)$. 
19. M. Bilal, L. Oyedele, H. Kusimo, H. Owolabi, L. Akanbi, A. Ajayi, O. Akinade, J. Delgado, Investigating profitability performance of construction projects using big data: A project analytics approach, Journal of Building Engineering. 26, 100850 (2019).

20. M. Guofeng, J. Jianyao, J. Shan, W. Zhijiang, Incentives and contract design for knowledge sharing in construction joint ventures, Automation in Construction, 119, 103343, November (2020). 